\title{
FIGURATIVE LANGUAGE IN AMIR HAMZAH'S POEMS
}

\author{
NOVIA KHAIRUNISA ${ }^{1}$ I WY DIRGEYASA ${ }^{2}$, CITRA ANGGIA PUTRI ${ }^{3}$ \\ ${ }^{123}$ UNIVERSITAS NEGERI MEDAN
}

\begin{abstract}
This study dealt with figurative language in Amir Hamzah's selected poems. The objective of this study were to investigate the types of figurative language found in Amir Hamzah's selected poems and to find out the literal meaning of figurative language found. This study was conducted by using qualitative method to solve the problems. The data of this study were phrases and sentences contained figurative language in the poems. The sources of data were six poems poems which had multiple series taken from Amir Hamzah's Poetry Anthology of Buah Rindu. The data were selected by using random sampling technique. For collecting the data, this study used documentary technique, and the instruments of data were documentary sheets. The data were analyzed by using descriptive qualitative method. The findings of this study are there twenty two figurative languages found as follows, three figurative language of metaphor (13.63\%), seven figurative language of hyperbole (31.81\%), five figurative language of personification $(22.72 \%)$ and seven figurative language of simile (31.83\%). The literal meaning of figurative language found in Amir Hamzah's poems were basically was about the love story of Amir himself and also talking about his longing to his mother.
\end{abstract}

Keywords : Figurative Language, Figure of Speech, Poem

\section{INTRODUCTION}

Poem is a literary work in patterned language. It can also be said as the art of rhythmical composition. Written or spoken, designed to produce pleasure through beautiful, elevated, imaginative or profound thoughts. Poem contains the expression of the poet's feelings, contains rhyme and rhythm, and expressed in precise words. According to Asmaul Khusnah in her paper (2008: 38) stated that poem is form of literature that encompasses a great emotions, feelings, or desires. Poem can be written for different reasons and therefore each poem has a different purpose. Some poems are written purely, to certain us,, others solely for the purpose of moral persuasion.

Understanding poem is not as easy as understanding other literary works. Dirgeyasa (2017:104) stated that understanding the meaning of poetry is truly difficult to do not only for the students but also the lecturers as well. It is really the most difficult subject to do among other literary works such as drama, prose, short story and, etc. This may happen because the poetry has its unique and distinctive features such as physical structure, linguistic feature and 
mental structure.

Another reason why poem is difficult to understand is the matter of the language used where the words in the poem contain many figurative words such as metaphors, hyperbole, personification etc. and symbols that are all not the real meaning. The words in poem are beautifully arranged in order to beautify as well as to deepen the meaning of the poem itself by using figurative words or language.

In line with the difficulty to understand the poems due to the figurative language used, Mahmood (2014:212) states figurative language is a type of language that uses words or phrases differently from literal meaning. Figurative language is used in any forms of communication, such as in daily conversation, articles in newspaper, advertisement, novels, poems and so on. Figurative language may be said to occur whenever a speaker/writer or the sake of freshness or emphasis departs from the usual denotation of words. Figurative language is same with figure of speech. Figurative language is not a device to state what is demonstrably untrue. Indeed they often state truth that more literal language cannot communicate, they call attention to such truths. Every use of figurative language involves a risk of misinterpretation, though the risk is well worth taking. Abrams (1999:96) states that figurative language is a conspicuous departure from what users of language apprehend as the standard meaning of words, or else the standard order of words, in order to achieve some special meaning or effect.

Figurative language often provides a more effective means of saying what people mean than direct statement. In the specific sense, figurative language may take the form of figures of speech such as metaphor, hyperbole, personification, simile, irony and etc.

Since language is a tool of communication, it can be spoken as well as written in expressing our feelings, thoughts, intentions and desires through language. So it refers figurative language can be found in both oral speech and text. But it will sound odd when people start talking figuratively with others. That is why figurative language is often used by people implicitly in written language with references literary works.

As mentioned before, poem is the example of literary works where language is figuratively used. However, nowadays people seem not to like to read poems, especially the old ones. In Indonesia itself, there are many famous poets with their popular masterpiece which deserve our attentions so that their works can be remembered all the time. One of those famous poets from Indonesia is Amir Hamzah. He is well-known as the 'King of the Poedjangga Baroeera Poets' then and now. Poems by him deal with the themes of love and religion and they often reflect a deep inner conflict. His diction are mostly using Malay language since he was born into a Malay aristocratic in the Sultanese of Langkat in Tanjung Pura, North Sumatera. One of his well-known works is called Malamfrom Poetry Anthology of Buah Rindu. 
Daun bergamit berpaling muka

Mengambang tenang di laut cahaya

Tunduk mengurai surai terurai

Kelapa lampai melambai bidai.

Figurative language that can be found from the poem above is personification. It can be seen in the first line of the first verse which states that the leaves turn to the face, where the leaves may not turn away and also in the fourth row, in the first verse as well, which says that the coconut is waving to the splint, where the fact that the coconut cannot waving its own leaves.

Therefore, this study will be focused on the figurative language in Amir Hamzah's selected poems. The reasons why the researcher chose this topic is because the researcher is interested in digging up, understanding as well as analyzing the poems of Amir Hamzah to find out figurative language used in the poems.

Also in this modern era many of young people are not interested in literary works, such as old poem. Perhaps, it is because reading poem is not something that people can get entertainment from. Reading poem takes a lot of time in order for us to obtain its meaning, so it is not becoming a thing mostly in young people's perspective. They tend to like something instant and that is what makes poems are getting left behind.

Therefore, by conducting this study, the researcher would like to appeal the interest of young people to start reading poems, because there are a lot of knowledge we can get by reading them.

\subsection{Semantics}

Semantics or also called semiotics, semiology, or semasiology is the philosophical and scientific study of meaning in natural and artificial languages according to en.wikipedia.org. Semantics is one of linguistics branches that focus in studying about language meaning. Saeed (2004:3) states, semantics is the study of meaning communicated through language. Language does not only have one kind of meaning, there are several kinds of meaning that need to be understood, this is happened because people do not only speak in the same rules but sometimes they create some styles of language both in written language and spoken language. This is why semantics help people to study about language.

Since semantics is the study about meaning. It concerned with what sentences and other linguistics object express, not with the arrangement of their syntactic parts of their pronunciation. Meaning is an idea that expressed by words, phrases, clauses, or sentences. Meaning is one of subject that discussed in linguistics. Linguistics itself is a scientific study of language and its structure, including the study of morphology, syntax, phonetics, phonology and 
semantics.

\subsection{Meaning}

In linguistics, meaning is the information or concepts that a sender intends to convey, or does convey, in communication with a receiver. Meaning has its kinds and there are some different opinions about the kinds of meaning according some linguists. However, Saeed (2004) simply divided meaning into literal and non-literal meaning (figurative language). Saeed states that non-literal meaning is just the same with all kinds of figurative meaning.

\subsection{Literal Meaning}

There are two kinds of meaning in studying semantics; they are literal meaning and nonliteral meaning. If a speaker is always speaking literally and means what his words mean, there will be no important difference between the linguistic meaning and the speaker's meaning. However a speaker sometimes speaks literally, therefore, means what the words mean. Literal based on the actual words or the real means does not use figurative or symbolic. When the speaker speaks literal he or she does not have hidden meaning in his or her words. Lexical meaning denotes what speaker means according to the dictionary usage.

Saeed (2004) says that literal meaning is where the speaker speaks in neutral, factually accurate way. It opposites with non-literal meaning where the speaker deliberately describes something in untrue or impossible in order to achieve special effect.

\subsection{Figurative Language}

Figurative language or non-literal meaning is part of language that uses words to mean something different from their ordinary meaning in order to emphasize an idea. Gibss (2015) states in his online encyclopedia that figurative language allows speakers/writers to communicate meanings that differ in various ways from what they literally say. However, figures of speech are not devices to state what is demonstrably untrue. Indeed they often state truths that more literal language cannot communicate, they call attention to such truths; they lend them emphasis.

\subsection{Poem}

A poem is the arrangement of words that contain meaning and musical elements. It is a piece of writing that expresses the writer's thought and feelings in order to set a mood; it can be happy or sad, simple or complex. In just a few words, a poem can say a lot. It can inspire and awe and can be a welcome escape into something that is totally wonderful. The words are chosen for their beauty and sound and are carefully arranged, often in short lines with rhyming 
or non-rhyming.

Dirgeyasa (2017) explains poetry uses language as medium. In fact, before the language is used as medium for poetry, the language itself has already owned meaning following the language rules and patterns which must be known and mastered. This is what makes poetry is difficult to understand. Nurgiyantoro (2005) as quoted by Dirgeyasa (2017) adds that the difficulty to understand the meaning of the poetry is due to its essences of having a) aesthetic, b) indirect expression, and c) compression.

\section{METHODOLOGY}

In conducting this research, the researcher applied a descriptive method. Research design is the arrangement of conditions for collection and analysis of data in a manner that aims at combining relevance to the research purpose with economy in procedure. According to Sugiyono (2016:9) states qualitative research is research method that based on post positivism philosophy, used for research in natural object condition, (as the opposite is an experiment) where the researcher as the key instrument, technique of collecting data conduct in combination, data analysis are inductive/qualitative, and the research finding emphasize the meaning more than generalization. While Kothari (2004:37) states descriptive research studies are those studies which are concerned with describing the characteristics of a particular individual, or of a group.

The data of this research included the phrases and the sentences contained figurative language in the six selected poems. The source of data in the study were six selected poems from Poetry Anthology of Buah Rindu, they were: Buah Rindu 1, Buah Rindu 2, Buah Rindu 3, Buah Rindu 4, Bonda 1 and Bonda 2. In analyzing the data, the researcher only focused on finding out the type of figurative language based on theory of Arvius (2003) by identifying as well as classifying each clause to their types. After finding out the type of each figurative language, the researcher then examined the figurative language found and to discover the literal meaning.

\section{FINDINGS}

After analyzing the poems, the total number of occurances of figure of speech in the poems were twenty two with classification as follows : three metaphors, seven hyperboles, five personifications and seven similes. There was one type of figure of speech that coud not be found namely irony.

To see the occurrences of figures of speech in Amir Hamzah's selected poems could have been seen in the table below: 
Table 1. Frequency of Figuratie Language

\begin{tabular}{cccc}
\hline No. & Type of Figurative Language & Frequency & Percentage \\
\hline 1. & Metaphor & 3 & $13.63 \%$ \\
2. & Hyperbole & 7 & $31.81 \%$ \\
3. & Irony & 0 & 0 \\
4. & Personification & 5 & $22.72 \%$ \\
5. & Simile & 7 & $31.81 \%$ \\
& Total & $\mathbf{2 2}$ & $\mathbf{1 0 0}$ \\
\hline
\end{tabular}

After analyzing the data and classifying the types of figures of speech in Amir Hamzah's selected poems, two research findings were found based on the problem of the study, the findings are presented as follows:

1. There were four types of figures of speech that found in Amir Hamzah's poems namely Metaphor, Hyperbole, Personification and Simile. The total number of figurative language found from the poem were twenty two. Spescifically, they were divided into three for metaphors, seven for personifications, five for hyperboles and seven for similes.

2. The literal meaning of figurative language found in Amir Hamzah's poems. The first was Metaphor, the phrase 'Kicau murai tiada merdu' had meaning about Amir who did not find the singing of birds was really entertaining him anymore since he got left behind by his lover.

3. The second was hyperbole with phrase 'Dikau alkamar purnama raya'. The meaning behind it was about Amir seeing his lover is like a full moon whose its bright can light up his dark night.

4. The third was personification. The clause 'Dari jauh suara melambai' had a literal meaning about Amir who faintly heard the voice of his mother calling out his name from far away.

5. The last was simile with the phrase 'Pelangi membangun laksana perahu'. This phrase did not have a specific meaning, but it only potrayed that the shape of a rainbow in backwards could be seen like a boat.

\section{DISCUSSION}

In conducting this research, the researcher took several relevant studies as a reference in making her own study. Therefore, the researcher would like to compare the finding of her study with previous research of figurative language. The finding study of Lonanda (2014) finds that there were five type of figures of speech occured in the short story. One of the figure of speech found was Irony which this figure of speech did not find in Amir Hamzah's poems. The similarity between these researches was the type of simile mostly found both in the short story and in Amir Hamzah's poems.

Figurative language is wording that makes explicit comparisons between unlike things 
by using figure of speech. Based on Arvius (2003) theory, figure of speech has an effect of how author can establish the creativity of a language. Figure of speech shows that the need to express thoughts and impressions that have no conventional verbal representation can make words produce various kinds of meaning. She futher explains that even the present work in her book only focuses on figure of speech in standard English, but it is hypothesised that the set of theoritical standpoints and method advoacted here can be used to study those in any human verbal language and also a few of the langugae spoken by different speech communities on this earth. In other words, it is assumed that the general principles behind theh use and character of figure of speech are quite similar accross language. At any rate, the occurance of figure of speech appaears to be a universal property of natural human language. Therefore, in this discussion it can be seen that the theory worked in Amir Hamzah's poems even though not all of the type of figure of speech applied in the poems.

This research is different from the previous research because of the object of this research is Amir Hamzah's Poems. To be specific this research only analyzed the series of Buah Rindu and Bonda. This research used the theory of Christina Arvius Alm which has five types of figures of speech. But in this research, the researcher only found 4 types of figures of speech., they are metaphor, hyperbole, personification and simile.

\section{CONCLUSIONS AND SUGGESTIONS}

Based on the previous data analysis, the conclusion of this research were:

1. The total number of figure of speech occurred in Amir Hamzah's selected poems was twentytwo cases. After analyzing and classifying each type of them, the result were three metaphors, seven hyperboles, five personifications and seven similes. And there was one type of figures of speech did not use in Amir Hamzah's Selected Poems was Irony.

2. The literal meaning of figurative language found in Amir Hamzah's poems from six poems were basically was about the love story of Amir himself which he portrayed into the series of Buah Rindu. While Bonda series were talking about his longing to his mother.

There were several suggestions that the researcher could offer to readers in conducting the related research. The suggestions were as follows:

1. It is suggested that the students of English Literature should learn more about figures of speech, especially in literary works such as poems, because there are a lot of figurative language that can be found so they can have a deep understanding of how exactly figurative language works.

2. It is suggested for the readers who want to know how figurative language are used in Indonesian classic poems, therefore they can appreciate more the works of Indonesian poets. 
3. For other researchers, they can obtain some information about figurative language and the result can be references for them to conduct a further study. But they need to be careful in determining or classifying the type of figurative language they found since there might be sentences that seem to have two kinds of figure of speech. Therefore, it needs a deep understanding of how figurative language works in each type.

\section{REFERENCES}

Abrams, M.H. (1999). A Glossary of Literary Terms. United State of America: Heinle $\&$ Heinle.

Arp,

Thomas R. And Greg Johnson. (2011). Perrine's Sound and Sense: An Introduction to Poetry.

13th Edition. United State of America: Wadsworth Cengange learning.

Arvius alm, C. (2003). Figures of Speech. Sweden: Student Literature. Lund.

Dirgeyasa, I. Wy. (2017). The Effort to Increase the Students' Achievment in Poetry Mastery through Semiotics Method. Australia: Australian International Academic Centre.

Eripuddin. (2017). The Analysis of Plot and Setting as Founs on The Jugle Book Movie. Riau: FKIP Universitas Pasir Pengaraian.

Griffiths, Patrick. (2006). An Introduction to English Semantics and Pragmatics. Edinburgh University Press: Edinburgh.

Hariyanto,. (2017). The Analysisof Figurative Language Used in the Lyrics of Firework by Katy Perry ( A Study of Semantics). Lampung University: English Education: Jurnal Tudris Bahasa Inggris.

Hayani, Riska. (2016). Figurative Language on Maya Angelou Selected Poetries. Samarinda University.

Nur, Syahril. (2015). Figurative Language and Imagery Analysis in William Shakespeare Sonnet. Universitas Negeri Gorontalo.

Nursyal,. (2009). Imagery and Figurative Language Analysis in two Poems by Robert Pinsky. UIN Syarif Hidayatullah.

Kearns, K. (2011). Semantics. Basingstoke: Palgrave Macmillan.

Kothari, C. R. (2004). Research Methodology: Research \& Methods. Jaipur: New Age International.

Lonanda, Fitria. (2014). The use of figurative Language in Characterization of The Nightingale and The Rose Short Story by Oscar Wilde. Padang: Andalas University.

M. Patel, Dr. Chirag. (2014). Imagery and Figurative Language in Wordsworth's Poem's "The World is too much with us" and "My Heart Leaps up". International Journal of Research. 
Murni, Sri Minda. (2010). Drama I. Pascasarjan Universitas Negeri Medan. Medan

Pateda, Mansoer. (2001). Semantik Leksikal. Jakarta: Pt Rineka Cipta

Saeed, I. John. (1997). Semantics. Malden: Blackwell.

Sehandi, Y. (2014). Mengenal Teori Sastra. Yogyakarta: Karang Berombak.

Sugiyono. (2016). Metode Penelitian Kuantitatif, Kualitatif, dan R\&D. Bandung. Alfabeta.

Jeffries, Lesley. (1998). Meaning in English: An Introduction to Language Study. United State of America: ST. MARTIN'S PRESS, INC.,

Perrine, Lawrence. (1974). Sound and Sense: An Introduction to Poetry. United State of America: Harcourt. 